\title{
Interaction and Interdependency between Actors to Follow-Up on Performance Auditing Issues
}

\author{
SARIMAH UMOR, ZARINA ZAKARIA \& NoOR AdWA Sulaiman
}

\begin{abstract}
The present study investigates the current state of actual condition that occurs when various actors interact and depend upon one another in resolving performance auditing issues through effective follow-up practice. The present research present findings from semi structured interviewed data involving 55 interviewees. An interpretive approach that is based on qualitative methods was employed to provide insight into the topic under study. Instead of interaction between auditor and auditees, the present study suggests that the regulator and media are among the actors that need to be strongly considered in the follow-up practice. In the case of regulators, it was discovered that earlier information in relation to performance auditing issues requested by regulator was mainly intended to secure availability of particular important evidence as well as to speed up further investigation and action by the regulator. However, this would not necessarily result in greater interaction with regulator, due to the embargo provision of Auditor General (AG) report until the report is tabled in Parliament. Meaning that, the information needs to be secure in terms of confidentiality before the tabling. Therefore, these shortcomings or challenges need to be addressed by the right authority. More so, in the case of media, policy makers often do not realize the rise of the media in shaping the people's views and influencing the conduct of actors in the network. Besides this, lack of interaction with media may also expose the inability of the government agencies to respond according to current trend and challenges. Follow-up for the resolution of an audit issue in reality may not be solved by the auditee themselves or one party alone. Hence, the need for reliance on other parties considered important regardless of the nature of interdependent, either direct or indirect and formal or informal. Interaction and interdependent between many actors are inevitable in the co-evolving era of postmodern network society. It means that there is an urgent need for deliberation process, value conflicts and the resolution of difficult issues through various autonomous interdependent actors. This is one of the first studies that explores the nature and extent of actors' interaction and interdependency in follow-up on performance auditing issues in public sector audit field.
\end{abstract}

Keywords: Interaction; Interdependency; Performance Auditing; Follow-up; Governance Network

\section{INTRODUCTION}

The present study attempts to explore conceptualization of core concept and assumption of governance network theory within the contextual framework of actors' interaction and interdependency within the practice of follow-up on performance auditing issues in Malaysia. It explores the condition that lead to the dynamic practice of current follow-up initiatives, which started from the second cycle of Government Transformation Program (GTP.2) ${ }^{1}$ under PEMANDU ${ }^{2}$. As well as the transformation initiatives in the follow-up practice championed by National Audit Department of Malaysia (MNAD), which interact with various other actors to solve performance auditing issues. These transformation initiatives provided an encouraging condition to depict interaction and interdependency between actors involved. The theoretical framework engaged in the present study depicts various interdependent social actors' interaction in the follow-up on performance auditing issues in practice through governance and networking.

The follow-up on audit issues are necessary to ensure that recommendations are appropriately addressed
(Masood \& Lodhi, 2015). As the follow-up practice now appears to be important for the rechecking of the responsiveness of auditees towards various issues raised pertaining to improper use of public fund, interaction and interdependence between actors like auditors, auditees, regulators and other, such as media are therefore inevitable in the resolution of audit issues. However, Pierre, Peters and de Fine Licht (2018) recently postulates that follow-up on performance auditing issues are merely a responsibility of auditors and auditees in which the nature of interaction limit interdependence on other actors like regulator who are able to take action as well as the media with their rising influence in shaping public perception. For this reason, recent literature has suggested to consider other stakeholders influence (Parliament, Media and Public) in this practice (Parker, Jacobs, \& Schmitz 2019). Meaning, follow-up is not an exercise limited to auditors and auditees interaction or interdependence alone. In reality, it occurs among the networks of actors either by deliberately intention in the sense that actors intentionally interact (Rhodes 1997) in which Pollitt and Bouckaert (2011) termed it as network phenomenon. Network type of study permits leveraging 
capability detained outside its scope of authority (Isett, Mergel, LeRoux, Mischen, \& Rethemeyer 2011) through interactions among structurally interdependent actors to improve their implementation abilities (Sorensen \& Torfing 2007; Klijn \& Koppenjan 2012).

In the field of auditing, particularly public sector performance auditing, research on networks has not yet fully be explored though it has emerged as important area of inquiry within the field of public administration (Sorensen \& Torfing 2017, 2016; Lecy, Mergel \& Schmitz 2014; Provan \& Kenis 2008) and public sector (Klijn \& Koppenjan 2016, 2015). In today's economic and political climate, interaction among various actors beyond organizational boundary seemed inevitable. Most notably inter-organizational relationship, collaboration, coordination, cooperation, negotiation and contributes toward problem solving and decision making. Rhodes (1996) defines governance as "process or governing; or a changed condition or ordered rule; method by which society is governed ( $\mathrm{p}$ : 653). Taking this definition in the context of performance auditing follow-up practice, it signifies most appropriate and indeed relevant.

The remainder of this paper is structured as follows. Section 2 provides background of the study and followed by description of theory of the study. Section 4 provides a review of the literature. Section 5 describes methodology of the study. The results are presented in section 6 while section 7 provides concluding remarks.

\section{BACKGROUND}

Performance auditing in Malaysia is under the responsibility of the Office of Auditor General (AG) or commonly refers as National Audit Department of Malaysia (MNAD). Auditors who are under AG portfolio are known as Government Auditors difference from their other counterparts, who are mainly the Internal Auditors within the government department and agencies. As such, public sector Auditors are known as government Auditors in Malaysia. This set of Auditors has a crucial role to play in ensuring public accountability with a mandate from Malaysian Constitution Articles 105-107 and Audit Act 1957. Under the provision of the Audit Act 1957, it is the responsibility of Auditor General (AG) office to audit the account of the Federation and States; Funds established in the State or the Federal Territory under Article 97/ (30 of Federal Constitution); public authorities; other corporate bodies in receipt of a grant or loan from the Federation or State; and other funds.

In the year 2012, the Government of Malaysia initiated a review in relation to follow-up on performance auditing issues championed by the MNAD. Led by an Auditor General (AG) as the head, in which the transformation initiative particularly at the last stage of performance auditing process enabled interaction between different actors into follow-up practice. The deficiencies of performance auditing impact and value have driven the
Government of Malaysia to initiate transformation by means of strengthening the monitoring aspect which involves more robust approach in undertaking follow-up action on performance auditing issues. Ever since then, the Government Transformation Program (GTP.2) that started in the year 2013, for which the MNAD, through AG's report, pooled all the relevant actors from different agencies to involve in the follow-up practice.

By revisiting the major initiatives that has undertaken by the MNAD and the Government of Malaysia in an effort to enhance follow-up practice, especially in relation to various actors' interaction and interdependence between them, there is a deeper appreciation for what the government, the MNAD, regulators, and other actors have invested in ensuring that Malaysia's image continue to improve. Despite many reform programs and policies that have been executed by the government, there are still setbacks or shortcomings in terms of its implementation (Siddiquee 2014). Thus, there is a strong reason to unpack how auditors, auditees, regulators, other relevant actors like media interact and dependence upon each other (interdependence) into the follow-up practice.

In the context of performance auditing, economy, efficiency and effectiveness (Vacca 2014) are trademark for every public sector performance auditing, which must be maintained to ensure sustainable public sector (Osborne, Radnor, Kinder \& Vidal 2015). Also, effectiveness and efficiency are synonym with auditing function as poses by auditors, particularly government auditors which mostly contribute the changes in the public sector (Pearson 2014). Nevertheless, issues of inefficiency and ineffectiveness are continuously been highlighted by elected parties through mass media due to repetitive case of corruption among public actors (Siddiquee 2010). Therefore, monitoring and evaluation on the performance auditing issues raised should be followed-up. Therefore, it is necessary in order to identify the sources of inefficiency, so that appropriate solution can be initiated to improve performance (Pettas \& Giannikos 2014). Further, the follow-up on performance auditing issues that is raised in the Auditor General report essentially created for tracking the audit recommendation implementation. The International Standard for Supreme Audit Institution (ISSAI) 3000 termed the objectives of follow-up as basically to help and augment the effectiveness of audit report; assisting legislature; evaluating the SAI performance and provide input to the enhancement policy with regards to performance auditing in the public sector context.

\section{THE Use Of THEORY}

Governance network theory according to Klijn and Koppenjan (2012) was built on evolving paradigm, for instance New Public Governance (Osborne 2010) that was surrounded with issues of complexities, interdependence and dynamics of public problem solving and service delivery. In this respect, governance network points to the 
formation of a structure or direction which cannot be externally enforced but as a consequence of the interaction of various actors and an arrangement of governing (Kooiman 1993). This is mostly attributed to unfolding different kinds of networks and function as mechanisms of governance (Rhodes \& Marshb1992; Marsh 1998). In the public administration context, this type of network offers flexible structures that are comprehensive, full of info, and beyond the administrative control.

Governance network theory is mostly defined as a horizontal articulation of interdependent but operationally autonomous actors who interact through negotiations. It consists of interdependent actors with different values, interests and strategies (Koppenjan \& Klijn 2004). As to date, none to limited number of prior studies has incorporated a governance network perspective in the public sector performance auditing and in particular the follow-up on performance auditing issues despite inter organizational challenging interaction between various actors. As the focus of previous literature is more on independent role, action and anticipation. Therefore, drawing from the governance network perspective in a way to assemble actors' interaction and interdependency, the present study explores and offer a wide-ranging view of the governance network theory based on actor interaction which should provide broad understanding about interdependence between them. As such, in order to ensure effective resolution of audit issues thus audit recommendations are implemented.

There are growing calls of discussion pertaining to different kind of governance network research, particularly in the formulation, implementation and solving the public sector issues such as condition that shape performance of public organisations through multilevel theoretical framework within public sector network (Whelan 2015); public sector organizational network (Klijn \& Koppenjan 2015, 2012); network approach to public governance (Bang \& Esmark 2009); construction of public value through collaborative network (Page, Stone, Bryson \& Crosby 2015); network performance (Herranz 2010); network effectiveness (Turrini, Cristofoli, Frosini \& Nasi 2010); performance measures (Agostino \& Arnaboldi 2015; Van Meerkerk, Edelenbos \& Klijn 2015); new spaces of interactions (Liddle 2015) and interactions between government and non-government actors in governance networks (Johnston 2015). The literature is full of writings on governance network approach in public sector and network performance as well as its effectiveness, but little of these writings emphasises on appraising this approach in public sector audit field, which indicate fruitful avenue for further exploration. With these issues surrounding the agenda of follow-up practice, thus the present study intends to ascertain to what extent "interaction" and "interdependencies" being operationalize by actors involved in the follow-up practice. The exploration of various actors' interaction and interdependence facilitates a clearer understanding about the formation of follow-up network, as illustrated in Figure 1.

\section{LiTERATURE REVIEW}

\section{FOLLOW-UP EVOLUTION}

Follow-up on performance auditing issues in practice as to date has received slight devotion in the literature (Morin 2014). Moreover, recent literature reveals that lack of follow-up has resulted in the lack of attention or focus on the resolution of audit issues and recommendation (Adi \& Dutil 2019). The importance of follow-up practice could be traced from the real value and impact resulted from performance audit activity which is through effective resolution of audit issues and recommendation. Also, the impact and value of performance audit on public sector organization (Raudla, Taro, Agu \& Douglas 2015; Bawole \& Ibrahim 2015) has received little attention in the performance auditing literature. The reason are many but most prominent is about whether performance audits have an impact in improving the auditee's entities (Yang 2012); usefulness from auditees perspective (ReichbornKjennerud 2015); resulted changes to the audited organizations (Morin 2014) and the contributing effect of such changes (Siddiquee 2014) need further exploration in the public sector performance auditing fields.

Public sector performance auditing is important as its fundamental purpose is to ensure and appraise the accountability of government through monitoring the operation and used of public funds (Liu \& Lin 2012). At the current condition, there are debatable arguments surrounding the limited interaction and interdependence between auditors-auditees in undertaking the follow-up exercise (Aikins 2012; Alwardat Benamraoui \& Westminster 2014; Funnell \& Wade 2012; Nalewaik 2013). This could be the reason for Abu Hasan, Frecknall-Hughes, Heald and Hodges (2013) in their concluding remark to state that limited interaction and interdependence between auditorsauditees alone in the public sector remains a risky undertaking. This is because it indicates various actors' interaction is important in addressing the audit issues and recommendation through effective follow-up. Therefore, if follow-up on performance auditing issues is to be geared toward performance improvement, it would be an advantage to broaden interaction and interdependence of actors in carrying out the follow-up on performance auditing issues.

Prior studies demonstrate that, issues surrounding the performance auditing follow-up could be many but mostly debated are unresolved and repetitive performance auditing issues due to lack of audit recommendations implementation (Funnell \& Wade 2012). In addition, the preventive effect by auditees does not actually exist (Morin 2014). For instances, the proof of whether the auditees are convinced or had taken improvement action cannot be fully confirmed due to their resistance and unsupportive attitude (Reichbornkjennerud 2015, 2014b). Although, numbers of audit recommendation is not the matter of concern rather its implementation are the ultimate goal. However, as identified by Reichborn-Kjennerud (2014b), auditees tend 
to be unresponsive toward audit recommendation implementation as result of incongruity to the audit report's; audit criteria, approaches, evidences, or assessments in its official answer to the Supreme Audit Institution (SAI). Nevertheless, in spite of this unresponsiveness and the auditees' protests, decisions in Parliament or PAC could force them to comply. Since the audited organization continuously face formal pressures from organizations, such as Parliament, the impact of the SAI's reports can differ depending on political provisions in Parliament (Reichborn-Kjennerud 2014a). Accordingly, social and political forces are also affecting the performance audit (Nath 2010). As all three authors (ReichbornKjennerud 2014a; Talbot \& Wiggan 2010; Nath 2010), agreed that influence of Parliament has an impact on performance auditing follow-up. More so, performance auditing report is used by the Parliament and its control committee to hold the auditees to account for unsatisfactory performance, management practice or lack of compliance in the policy area (Laegreid 2013).

Based on the idea of Klijn and Koppenjan (2012), governance within the network literature permit fruitful solution to public sector issues due to horizontal interaction by various actors at multi-level setting who collectively coordinate their interdependencies. According to these authors, governance in the context of network studies could be regarded as a way of strategy in public sector organization that intend to initiate, facilitate, mediated the network flow. Thus, a governance network in the context of the present study is defines as a relatively wide-ranging of parallel connection of inter-reliant, but operationally independent actors, who dependent upon each other (interdependency) through interaction to tackle and overcome issues in public sector (Sørensen \& Torfing 2007).

\section{INTERACTION}

In the network study context, Provan and Kenis (2008) suggest that, "every actor must be responsive to the goals of both their employing organization and network," which may create conflict (p. 239). Similarly, from the governance network perspective, complexities resulted from actor's interaction are not free from considerable challenges in governing relationships (Vangen \& Huxham 2013). Building on this, the governance network core concept suggested in public sector context, although the theory is not for everything or every complex problem (Klijn \& Koppenjan 2012), but the essence of relationship realized from interaction and interdependency as uplifted by this theory, could be applied to address problem related to conflicting situation, coordination problem and complexity due to many actors involvement.

Conversely, a face-to-face interaction is more likely to nurture the type of collaboration as propose in the present study (Ostrom 2005). Interaction is also thought to enable "social influence" or the norm to hold in the collaborative process, which can help the actors to understand common understanding about the issues and prevent barriers to shared action (Oliver \& Myers 2003). Therefore, when there is an interaction, a relationship is formed that exposed to more challenging condition and consequences. According to Bobek, Daugherty and Radtke (2012), in many circumstances, audit engagement challenges were resolved by increasing interaction with other auditors and most importantly the auditees. Interaction with audited parties (auditees) is considered important as all the action executed through follow-up initiatives is meant for audit recommendation implementation. This action should be advocated by auditees as they are the one who must take action based on the monitoring and scrutiny from various actors.

Additionally, the importance actors' interaction closely relates to study within the performance auditing field from the perspective actors' and forum relationship (Bovens 2014). However, the actors' and forum relationship have been investigated involving other actors, such as the Parliament, the Public Account Committee (PAC), auditors, auditees, and the media. This relationship is termed as a horizontal accountability relationship (Klein \& Day 1987; Mulgan 2003; Schillemans 2011; Scott 2000). Although, many actors are involved in the performance auditing field in the above horizontal relationship, but little is known about their interaction. More so, prior research has reported interaction that exists mainly between actors during the planning and implementation stages. Such interaction is normally limited to auditor and auditees, to the extent of the Parliament. While for follow-up practice it involves a number of different actors, in which their nature of interaction and interdependency between the actors, have not been explored as summarized in Figure 2 below.

\section{INTERDEPENDENCE}

According to governance network theory, autonomous interdependent actors who interact chooses strategies based on their perceptions of the world which then affect their perceptions on the problems as well as the solutions for it (Schon \& Rein 1995). However, if actors have different view about the nature of the problem and encountered problem, like lack of information or even the quality of the information, then some of them may have different perception which may causes misunderstanding (Klijn \& Koppenjan 2014). Diverse perceptions or frames about the nature, reasons, and effects of problems as well as their solutions will most likely have unproductivity effect in a network (Hajer \& Wagenaar 2003).

Based on Klijn (2008) and Klijn and Koppenjan ( 2012) GNT perspective, the present study postulates that, lack of understanding as well as deficiency in interaction may likely influence the actors' perception or frames of their world views. This is because, issues raised sometimes as a result of performance auditing could be due to mistake, miscommunication, as well as lack of documentation given to auditor, and while some of the legal terms in contract documents are wrongly interpreted. From the network 
research perspective, "networks develop and exist because of the interdependency between actors" (Klijn 1997, p. 31). Therefore, interdependency can be proclaimed at the outset as a key challenge to better understand the network problem. This could be the reason, interdependency claimed to be mirroring the networked nature of the world condition (Castells 2000). Interdependency is also a triggering point for the depiction of certain institutional arrangements in the public domain (Rethemeyer \& Hatmaker 2008). Particularly, interdependency mooted the cause and consequence of collaboration as well as coordination among agencies and organizations (Hillman, Whiters \& Collins 2009). Organizations that are to collaborate are interdependent to some extent or are embedded in a network/environment of interdependence (Thomson \& Perry 2006).

Hertting (2007) describes and defines how interdependencies are interpreted as an incentive structure for governance network formation. According to him, it firstly based on contextual mechanism, such as perceived interdependencies resource and strategic dimensions of interdependencies. In which it stated as the analytically interdependencies that can be divided into resource dependencies and dependency relationship that execute strategic externalities. Secondly, a resource dependency is handled through resource exchanges while strategic externalities are handled through control exchange. Thirdly, it is about perceptions together with desires that stimulate actors to build institutional arrangements, which are regarded as mutually perceived, mutually recognized and changing interdependencies.

\section{Methodology}

Qualitative methods are mostly prospective to be the appropriate method to explore issues under study in detail from the view sharing, expectation, perceptions and beliefs of the actors concerned. Patton (2002) stated that qualitative methods allow examination of a social issue in a comprehensive way and consent the researcher to gather rich information. This method is most likely will help the researcher to enhance the understanding of social phenomena with a small number of people or cases. As such, the qualitative research is appropriate for the present study because it is used to study social phenomena as well as to seek detailed and elaborative explanations into "why" a phenomenon occurs (Bryman \& Bell, 2011). An interpretive approach based on qualitative methods is used to provide insight into the topic under study about human belief and practices. Additionally, methodology can be defined as the procedures of collecting data, describing, explaining and predicting phenomena using chosen methods or techniques (Bryman, 2012; Creswell, 2013). The methodology aspect described in detail attainment of the research objectives by the qualitative data gathered through semi structured interview. This is in line with assertion made by Chua (1986), "what is a correct" research method that will depend on how truth is defined. Therefore, in the present study, the focus is not only to understand and explore the nature and extent various actors' interaction in follow- on performance auditing issues but also to bring out the existence of interdependency between the actors. Based on the above arguments, the present study draws on features of interpretive perspective paradigm for its methodological approach

A qualitative research design is employed for the current study. There were 4 groups of 55 interviewees for the research that consist of 14 auditors; 11 auditees; 15 regulators; and 15 other relevant actors. Furthermore, an understanding of the perspectives of the key actors are sought in order to aid the investigation of the practice of follow-up on performance auditing issues in Malaysia. Semi-structured interviews via Snowball Sampling Method (SSM) were used to collect data. More so, qualitative software package mainly used to manage the fairly huge number of interviews data that involved 55 interviewees. This is in line with the claims made by longstanding literature that the software packages only use to organise large volumes of data and not to develop strategy to formulate the analysis (Myers, 1997). Thus, familiarization of data using qualitative software package is mainly to get closeness to data and interactivity; data exploration; code and retrieval functions; data organisation; and finally searching and interrogating the database.

\section{FINDINGS AND DisCUSSIONS}

The present study specifically deploys governance network theory to explore the nature and extent of follow-up practice that occurs through actors' interaction and interdependency, namely the auditors, auditees, regulators and other related actors. Interaction and interdependency between actors in the problem-solving activities are based on the actor's values, views, interests which in turn influence the strategies they choose. That is to say, their interaction is collectively aimed at facilitating and launching a process towards resolving problems as well as addressing implementation problems. First and foremost, interaction with audited parties (auditees) is considered important as all the action executed through follow-up initiatives is meant for audit recommendation implementation and resolution of audit issues. This action should be advocated by auditees as they are the one who have to take action on audit recommendation based on the monitoring and scrutiny from various actors. Auditor 1 said:

"Auditees initially need to take action on audit recommendation. But, rarely do they do so. So, we need to follow-up together with the auditees and also the enforcement agencies. So, we set up Follow-up Division (FUD). One of the responsibilities of the FUD is to make an engagement with the auditees at ministerial level as well as others. We start to communicate with them on how to solve the issues" (AUDITOR 1) 
Another interviewee (Auditor 6) revealed a similar view and emphasized on close interaction with auditees. As claimed by this interviewee, auditors need to interact with auditees regularly. Through interaction with auditees, it is perceived that the auditees are able to response accordingly.

"But sometimes, further understanding is needed, so we need to make more engagement, I would say, more engagement is necessary. Yes! It is true auditors rely on documents. But, in order to understand how it works? How the documentary evidence become in that manner? How the people did it? So, more engagements are needed with auditees" (AUDITOR 6).

Interaction with regulators is another form of relationship that emerged from the interviewed data. According to the most interviewees, interaction with the regulator is very important as evident in their statement. For instance, Regulator 6 argued, it would be advantageous for them as an investigator for punitive issues, if National Audit Department of Malaysia (MNAD) could give them the report or reveal the audit issues earlier before the tabling of AG report in Parliament. While, Regulator 9 said, in the future they want the follow-up secretariat to provide detail about the issue, particularly the police report number before calling them to any meeting or discussion session. According to this regulator, if other actors plan to discuss or pass the issue to them for further investigation, a detail about the issue together with police report number is required. Even the auditees also conveyed their stand that punitive audit issues should be exposed so that necessary actions are taken. Although, some actions are taken internally by the auditee organization, but it is basically for corrective audit issues that need improvement in terms of system and procedures. While for punitive audit issues, the auditees perceive auditors, regulator as well as other actors must understand cooperation between with various actors in resolving the audit issues as very important.

"But what's important is, we were seen as taking action on every significant audit issue raised in the AG report. Now is very action oriented. But we need to be informed much earlier so that we have more time to look on the issues and secure the evidence. Not after tabling of AG report but before that” (REGULATOR 6).

"In order for us to open a case, we need a police report. So, basically when the auditor presents the punitive audit issues with their slide presentation, we will look for this information" (REGULATOR 9).

"Punitive audit issues will be discussed during the Action Committee of Auditor General Report (JTLKAN) meeting which involved a network of actors from various agencies. We can get latest updates on the issues in terms of investigation and action during the JTLKAN meeting. This is very important meeting and everybody understands about that. For corrective audit issues, we have not much problem as we could do it internally. But not for punitive audit issues." (AUDITEE 2).
Although, in agreeing on the interaction with various actors in tackling the audit issues, interviewees were of the opinion that this engagement, particularly with regulators should start earlier. For instance, Auditor 14 admitted the importance of earlier interaction.

"My opinion is, the involvement of these entire enforcement agencies should start earlier not until it been reported and tabled in Parliament. They should be informed earlier than that, so that action can be taken much earlier" (AUDITOR 14).

In the same vein, Auditor 9 also explains about their interaction with regulator.

"We will synchronize with Public Service Department (PSD), we will not turn the status of the issue into green because we knew the case has been passed to PSD. So, we need to wait for the decision made by the investigation committee" (AUDITOR 9)

Based on the above claimed, the present study argued that prior information in relation to performance auditing issues requested by regulator mainly intended to secure availability of particular important evidence and speed action by regulator. However, this would not necessarily result in greater interaction with regulators, due to the embargo provision of AG report until the report is presented in Parliament. Meaning that, the information needs to be secure in terms of confidentiality before the tabling.

Despite interacting with various actors mentioned, the interviewees seemed to agree and admitted that interaction with other actors, such as media, Internal Audit and Integrity Unit are also considered important. Interaction with all these actors should be uplifted in terms of timing, extent and effect. For example, other actors, like Integrity Unit at the auditee organizational level claimed that, their interaction with regulator are much closer and effective. As argued by Other Actor 9,

"People keep arguing about what the Integrity Unit has been doing at the government agencies level? That's why I said the perception is everywhere. Only thing is how we try to overcome it. First, if we found there are elements of corruption, we need to directly inform the MACC. Same should be happened in the Auditor General Reporting process. If the auditors found out there are element of noncompliance, then they should directly channel this information to MACC. It shouldn't be done during the exit conference but before that. Earlier as possible" (OTHER ACTOR 9).

While Regulator 2 argued that,

"If possible or necessary, engage with professional auditors from private sector. I know, it is very costly to hire those private professional. They are earning higher pay at private and why should they work in government. Perhaps then, engage them as third-party consultant in certain cases for special suspicious cases, engage to best possible" (REGULATOR 2) 
In the same vein, Regulator 11 suggested on the important of seeking legal advice on every significant audit issue raised in the AG report. Particularly, if the issues are related to legal provision and sometimes could be misinterpreted by the auditors themselves. The Regulator 11 argued that,

"Only thing is, at the investigation level, there is a need to clarify on legal matters. Therefore, it is better to engage the legal advisor. But now it is good as they make the involvement of legal advisor as necessary. So at least they know, the legal advisor could give proper advice or opinion on legal aspect" (REGULATOR 11).

As indicated by other interviewees, current means of various actors' engagement in follow-up initiative enabled the actors to interact in informal approach which they regarded as a way to get more information on particular complex issues. Auditor 6 explained,

"The reason is to inform the public on our transparency to public, public will see on their own, the progress of each issues highlighted in the AG report. So, sometimes we just need have a chat over coffee in the office. Like just we get a coffee in the office and we just chit chat... you can get a lot of information from there. Rather than if it is in the meeting. Because, in the meeting, I believe, many of them would like to protect themselves in the meeting" (AUDITOR 6).

Despite facing with challenges, majority of auditors admitted more interaction with various actors outside the MNAD organization is essential and should be harnessed. Auditor 6 and 7 said.

"So, in doing follow-up on audit issues nowadays, Ifound communication is very important since we need to engage with many people outside our organization" (AUDITOR 6).

"Our experience like at the state level, when we firstly arrange an exit conference meeting, there was resistance from the agency. Therefore, we asked the State Secretary to get involved and in fact we gave him a copy of our report. We also sent to the State Chief Minister. This is what we can do. So, the engagement is there. Communication is there" (AUDITOR 7)

Therefore, interaction as discussed above is not limited between auditors and auditees as the interview findings suggest that the media is evolving actor (from other actors' group) that might exert influence into the follow-up practice. Evolving role of media according to majority of the interviewees to some extent has exerted positive as well as negative influence. Therefore, to minimize the bad influence of media in the follow-up initiative, more interaction is needed with media. Complex decisionmaking processes indicate that negative media attention has a significant negative impact on network performance (Korthagen \& Klijn 2012). Hence, interaction with the media is inevitable in the follow-up initiatives. The findings of the present study have strong arguments on the need to interact with media as admitted by all the interviewees. General question on how media has impacted their role, function and work while experiencing the follow-up practice suggest more negative impact than positive.

According to Other 14, previously, indeed every year, after the tabling of AG report at Parliament, copies of the AG report will be disseminated to all media actors without much interaction with them. Media is sometimes are overlooked and left alone to understand the large volume of AG report. As such, the media tend to highlight AG report issues according to their logic, interest and intention. The strategy to make an engagement with media was suggested by former Communication Minister by initiating the town hall session as part of follow-up initiatives. Through the town hall session, the audited parties are able to give explanation to media. Therefore, once the media have clearer understanding, they might come to conclusion, not to highlight the issues extensively to any further extent. Other 14, further argued that,

"Appropriate engagement between government agencies and media to give explanation on why such issue happened is needed. So that, when the issue was raised in the $A G$ report and presented at Public Account Committee (PAC) briefing session, the issue just not suddenly burst. Because we have to remember, public are watching what the government agencies are doing. It involves public money. Public wanted to know what actually happened. Therefore, media function as middleman that linked or build relationship between public and government. One of the roles of media is to highlight what are the government is doing. But now, through this initiative, only few issues have been highlighted. Maybe one or two pages. Not like previous, more than five pages. Same in the context of electronic media. No more highlighting issue more than three to five days (OTHER ACTORS 14).

On this condition, Auditor 1 said,

"After the Auditor General's reports tabled at Parliament, there was new initiatives introduced, we called it town-hall session with media. We get them involve (the media) so they can be informed about the latest status and updates on any particular audit issues" (AUDITOR 1).

While other actors such as Integrity Unit admitted the importance of forming a relationship with media. In Similar vein, another regulator argues why the need to have close and continuous interaction with media Others Actor 9 and Regulator 15 said,

"Media has the ability to influence public perception. Therefore, I would rather suggest all those who are currently involved to follow-up on audit issues to have a close engagement with media. One of the good initiatives that I could see the MNAD has initiated is the town-hall session" (OTHER ACTOR 9)

"In the context of MACC, we have a close engagement with media. We have special division to channel out or release 
information, our progress as well as initiatives taken so far. This division was formed particularly to handle the public. So, we channel out information mediator like media. We need to do so, because we want to inform the public that MACC do not have prosecution power (OTHERS ACTOR 9).

Whereas, as generally admitted by majority of the interviewees, some of the reason behind the justification for interaction with media are also exposed. For instance, Auditor 8 said,

"Well, on behalf of government we need to answer back to media, so the Chief Secretary General to Government of Malaysia came out with the idea of town hall. Town hall session with media gives opportunity to media to ask questions and auditees will answer. Things that presented during the town hall session is on the punitive action. Actions that have been taken will be highlighted. For example, statistic on number of issues in which investigation paper have been open and which case been proposed for disciplinary action" (AUDITOR 8).

At this juncture, the present study believed in the extent to which various actors' interaction has an impact on the follow-up initiative. As proposed by the above interviewees, relevant actors as well as some informal technique need to be considered in operationalizing the interaction. The responses gathered from the interviewees demonstrate that interaction with relevant actors is more important with some other possible factors. Based on the above situation, the present study argued that, interaction with right authority or external actors are important in augmenting the effectiveness of follow-up practice. Meaning that, audit institution needs to interact with relevant actors in order to solve punitive audit issues. As such, the present study argued that, interaction contributes to the effectiveness of follow-up practice.

Whereas, interdependency between actors is also noted from interviewed data as resolution of audit cannot be achieved due to the nature of audit issues with punitive elements. Punitive elements are like waste, extravagance, embezzlement and negligence. In such a condition, there are needs for reliance on each other based on every actor's capability such as enforcement agencies like Police and Anti-Corruption Agency to take action on the issues. Besides this, strategies chose by the actors in a joint force depend on their justification, needs, views and their world view. Collectively, in the context of follow-up on performance auditing issues, it is indeed evident that interdependent between the actors occurred. According to Hillman, Whiters and Collins (2009), interdependence has a cause and consequence of collaboration as well as coordination among agencies and organizations. As the majority of the interviewees perceive that reliance and support between auditors, auditees, regulators and other relevant actors are very important to tackle the audit issues and particularly the audit issues with punitive elements. They belief interdependence between various autonomous social actors have the merit to interact more effectively to take up the issue for further appropriate action. Auditor 1 confirmed that interdependent between various actors in current follow-up initiative transpired through the Action Committee of Auditor General Report (JTLKAN).

“Auditor General Report Action Committee (JTLKAN). This is high level meeting. Meaning that, it will be executed after the Auditor General's report tabled in Parliament. A month after or else within a month or two months after the presentation, we will hold JTLKAN. JTLKAN will be chaired by the Honorable Auditor General and members of JTLKAN are from the Attorney General Chamber office; representative from Anti-Corruption Commission (MACC); Royal Malaysian Police, Public Service Department; representatives from the Treasury, Economic Planning Unit and we will also call Chief Secretary of the said ministries to discuss on the issues. They will come to give an explanation or an answer to the Committee. Also, on the issues itself, we will see, and we will channel out to MACC, the police or the Public Service Department (PSD) for further investigation and action" (AUDITOR 1).

In similar vein, Regulator 5 stressed that interdependence of various actors helps to uplift reliance and support from enforcement agencies, audited organization, audit institution as well as other actors from different organization. This is regarded as a good sign for resolving punitive audit issues. It also opens the door for more interaction with relevant agencies, particularly dependence upon enforcement agencies as affirmed by Auditee 6,

"I think it goes back to the matter of enforcement. When involve punitive issues, then it will depend on these agencies to take further action and investigation" (AUDITEE 6)

The interview findings also demonstrate that actors who engage in active interaction with others, outside their organization will be allowed for interdependence among them to resolve a problem. This is described and defined as interdependence strategy for the governance network formation (Hertting 2007). In this respect, the interviewees (Auditor 5, Regulator 13, Other Actor 12 and Auditee 10) acknowledged the existence of this form of interdependence among them. The underlying reason for interdependence as conveyed by interviewees is for the purpose of sharing common goal, which is to resolve the audit issues. This means that, auditors, auditees, regulators and other actors understand that they need to interact and depend upon each other in the resolution of audit issues that will eventually contributes to the effectiveness of follow-up practice. For instance, majority of the interviewees believed that a single actor's attempt to follow-up on punitive audit issues may be incomplete.

"Yes, we raised and report the issues. This is within our capacity. We need support from MACC and AGC and other enforcement agencies as well. So, we will communicate 
between us. I believe this is the only way. That's why I said, we need to work together with other stakeholder. We need support from enforcement agencies" (AUDITOR 5).

\begin{abstract}
"We need to have a good relationship and communication with those involved particularly the auditees and auditors in order to get more information. The auditor in particular wanted us to do further investigation and we provide our point of view based on their information. The information, we can get it either from auditor or auditees" (REGULATORS 13).
\end{abstract}

"The auditors provide information and same goes to us, we do help. In my case, the auditees rely on internal audit unit. We help the auditees in coordinating the feedback answers" (OTHER ACTOR 12 - INTERNAL AUDITOR).

"Follow-up has pushed us to work together with others. So, we need to provide whatever information requested from us. In fact, we also want the issue to be resolved quickly. Basically, for corrective audit issues we will take immediate action but for punitive issues, we take sometimes as not only we did the investigation to provide sufficient evidence, but the enforcement agencies will take care of it. We will provide all the support requested" (AUDITEE 10).

The above quotations explain the important of interdependence between actors who support one another to resolve the audit issues. It also shows that the interviewees acknowledged that audit issues with punitive elements have encouraged the manifestation of interdependence among different actors. The finding also indicates that; interviewees have similar understanding about punitive audit issues as they believed should be addressed through actor's interdependency and this eventually influence the formation of follow-up network.

Thus, it is inevitable that interdependence is a predominant feature in governance network among interacting actors in which consequently leads to the construction of relationship between actors' concern to achieve their goals (Kickert, Klijn \& Koppenjan 1997). This could be achieved as when the audit institution starts to cooperate with others outside their own organization. The reason is numbers of audit queries can be reduced as the cooperation directed to action-oriented relationship. The significance of interdependent among interacting actors in the follow-up initiative in Malaysia advocated by MNAD is evident from the majority of interviewees' acknowledgement on the subject. Thus, the determination and movements to embrace follow-up on audit issues in Malaysia that initiated from MNAD which functionally they lack with sanctioning power and as a result of that they need some kind of exchange from other actors in order to be able to implement their goals (Hertting, 2007). On such a continuum, this paper argued that, interaction between actors in the follow-up practice causes interdependence among the actors in tackling the performance auditing issues. This will likely contribute to the effectiveness of follow-up practice, in which consequently augment the values and impact of performance auditing activity.

\section{Conclusion And Future Direction}

In the present study, findings have revealed that interaction between actors enable them to share opinion, views, and information on significant information in order to resolve the audit issues. Besides this, there are also strong indications of interdependence between the governance actors (auditors, auditees, regulators and other actors) in the current follow-up practice. Based on this, the present study has presented the views of various actors about recent initiatives involving the practice of follow-up on performance auditing issues in Malaysia. By strongly considering their responses and perspectives on the issue, it provides evidence to explain the nature and extent of current follow-up practice which are initiated to address demands placed on governments for improved usage of public funds through performance auditing in Malaysia. Most notably, the present study is able to explore and reveals interaction and interdependency between auditors, auditees, regulators and other relevant actors. It finds that, they interact and depend upon each other in order to discuss, deliberate, as well as disseminate the issues for further investigation and action. It also finds that, governance networks are based on the interaction and interdependence of the four categories of actors that poses different values, interests, which then collectively choose their strategies (Klijn \& Koppenjan 2012) and solution for action (Klijn, Steijn \& Edelenbos 2010). Furthermore, what is designated by GNT are three core features, such as values, interests and strategy choose by the actors involved. Additionally, the present study reveals something more interesting. As it shows that the interaction of various actors and strategies chosen are not only influenced by their values or interests, but more importantly by the capability, as well as possible influence that could be exerted by the actors concerned. For example, if the audit issue has criminal elements, it is doubtful that MNAD are able to do it alone beyond their mandate to audit and report. While, auditees may have an element such as conflict of interest or lack of ability to do it alone. In such a case, the police are the right to do the follow-up investigation and take further action. Therefore, when all relevant and related actors interact as well as depend upon one another in effective manner, problem related to audit recommendation implementation could be overcome. Importantly, the media need to be managed and continuously interact with one another.

In capping, the present study finding indicates that follow-up practice depicts mixed results, in the case of MNAD have been instrumental in championing follow-up initiatives as well as ensuring the success of this practice. In the case of Malaysia, the way of follow-up on performance auditing issues being practiced these days have good impact and advantages, but at the same time, this practice poses numerous unexposed challenges. 
Follow-up practice has been successfully used to diversity of key actors' interaction and interdependence. Hence, the present study has succeeded in exposing problems and obstacles constraining the effectiveness of follow-up practice of the government, which have been initiated through the GTP. 2. As such, it is hoped that policy makers can take into account these challenges to be immediately addressed to show the real purpose and spirit for introducing a transformation initiative within the follow-up practice. All the challenges if can be reduced through governance network arrangement, has a very high probability in making follow-up practice as one of the monitoring mechanisms for public sector.

Since this research emphasized the nature and extent of actors' interaction and interdependency in follow-up practice, it may therefore be argued that complete evidence on the resolution of particular audit issues may have been overlooked. Therefore, future research could attempt to expand this study through case study method. The findings from this study also could be used as constructs for future quantitative research to provide statistical evidence about interaction and interdependency in influencing the effectiveness of follow-up practice.

\section{REFERENCES}

Abu Hasan, H., Frecknall-Hughes, J., Heald, D., \& Hodges, R. 2013. Auditee perceptions of external evaluations of the use of resources by local authorities. Financial Accountability \& Management 29(3): 291-326.

Adi, S., \& Dutil, P. 2018. Searching for strategy: Value for Money (VFM) audit choice in the new public management era. Canadian Public Administration 61(1): 91-108.

Agostino, D., \& Arnaboldi, M. 2015. How Performance Measurement Systems support managerial actions in networks: Evidence from an Italian case study. Public Organization Review 15(1): 117-137.

Aikins, S. 2012. Determinants of Auditee Adoption of Audit Recommendation: Local Government Auditors' Perspectives. Journal of Public Budgeting, Accounting and Financial Management 24(2): 195-220.

Alwardat, Y. A., Benamraoui, A., \& Westminster, L. 2014. Value for Money and Audit Practice: Lessons and Facts from the Literature. Life Science Journal 11(2): 86-98.

Bang, H., \& Esmark, A. 2009. Good governance in network society: Reconfiguring the political from politics to policy. Administrative Theory \& Praxis 31(1): 7-37.

Bawole, J. N., \& Ibrahim, M. 2015. Contesting Claims on Measuring Performance in the Public Sector Using Performance Audits : Evidence from the Literature. Public Organization Review.

Bobek, D. D., Daugherty, B. E., \& Radtke, R. R. 2012. Resolving audit engagement challenges through communication. Auditing: A Journal of Practice \& Theory 31(4): 21-45.

Bovens, M. 2014. Two Concepts of Accountability: Accountability as a Virtue and as a Mechanism. In Accountability and European Governance (pp. 28-49). Routledge.

Bryman, A. 2012. Social Research Methods. 4th edition. Oxford University Press: New York.
Bryman, A., \& Bell, E. 2011. Business Research Methods. Oxford University Press: USA.

Castells, M. 2000. Materials for an exploratory theory of the network society1. The British Journal of Sociology 51(1): 5-24.

Chua W. F. 1986. Theoretical constructions of and by the real. Accounting, Organizations and Society 11(6): 583-598.

Creswell, J. W. 2013. Research Design: Qualitative, Quantitative and Mixed Methods Approaches. Sage publications.

Funnell, W., \& Wade, M. 2012. Negotiating the credibility of performance auditing. Critical Perspectives on Accounting 23(6): 434-450.

Hajer, M., Hajer, M. A., \& Wagenaar, H. 2003. Deliberative Policy Analysis: Understanding Governance in the Network Society. Cambridge University Press.

Hertting, N. 2007. Mechanisms of governance network formation - A contextual rational choice perspective. In Theories of democratic network governance (pp. 43-60). Palgrave Macmillan UK.

Herranz, Jr, J. 2010. The logic model as a tool for developing a network performance measurement system. Public Performance \& Management Review 34(1): 56-80.

Hillman, A. J., Withers, M. C., \& Collins, B. J. 2009. Resource dependence theory: A review. Journal of Management.

Isett, K. R., Mergel, I. A., LeRoux, K., Mischen, P. A., \& Rethemeyer, R. K. 2011. Networks in public administration scholarship: Understanding where we are and where we need to go. Journal of Public Administration Research and Theory 21(suppl_1): i157-i173.

Johnston, K. 2015. Public governance: the government of nonstate actors in 'partnerships'. Public Money \& Management 35(1): 15-22.

Kickert, W. J., Klijn, E. H., \& Koppenjan, J. F. M. 1997. Managing Complex Networks: Strategies for the Public Sector. Sage.

Klein, R., \& Day, P. 1987. Accountabilities: Five Public Services. London: Tavistock.

Klijn, E. H., \& Koppenjan, J. 2016. The Shift toward Network Governance. Theory and Practice of Public Sector Reform 158.

Klijn, E. H., \& Koppenjan, J. 2015. Governance networks in the public sector. Routledge.

Klijn, E. H., \& Koppenjan, J. 2014. Complexity in governance network theory. Complexity, Governance \& Networks 1(1): 61-70.

Klijn, E. H., \& Koppenjan, J. 2012. Governance network theory: past, present and future. Policy \& Politics 40(4): 587-606.

Klijn, E. H., Steijn, B., \& Edelenbos, J. 2010. The impact of network management on outcomes in governance networks. Public Administration 88(4): 1063-1082.

Klijn, E. H. 2008. Governance and governance networks in Europe: An assessment of ten years of research on the theme. Public Management Review 10(4): 505-525.

Klijn, E. H. 1997. Policy networks: An overview. Managing Complex Networks: Strategies for the Public Sector: 14-34.

Kooiman, J. 1993. Modern Governance: New GovernmentSociety Interactions. Sage.

Koppenjan, J. F. M., \& Klijn, E. H. (2004). Managing uncertainties in networks: a network approach to problem solving and decision making. Psychology Press.

Korthagen, I., \& Klijn, E. H. 2012. Two clashing logics: the influence of media logic and mediatized politics on decision making processes in governance networks. In International Research Society for Public Management conference, Rome (pp. 11-13). 
Laegreid, P., \& Christensen, T. 2013. Transcending New Public Management: The Transformation of Public Sector Reforms. Ashgate Publishing, Ltd.

Lecy, J. D., Mergel, I. A., \& Schmitz, H. P. 2014. Networks in public administration: current scholarship in review. Public Management Review 16(5): 643-665.

Liddle, J. 2015. Bridging the Gaps in Multi-Level Governance: New Spaces of Interactions and Multiple Accountabilities in English Sub-National Governance. Multi-Level Governance: The Missing Linkages (Critical Perspectives on International Public Sector Management, Volume 4) Emerald Group Publishing Limited, 4, 217-245.

Liu, J., \& Lin, B. 2012. Government auditing and corruption control: Evidence from China's provincial panel data. China Journal of Accounting Research 5(2):163-186.

Marsh, D. 1998. Comparing Policy Networks (p. 53). Buckingham: Open University Press.

Masood, A., \& Lodhi, R. N. 2015. Factors affecting the success of government audits: A case study of Pakistan. Universal Journal of Management 3(2): 52-62.

Morin, D. 2014. Auditors General' s impact on administrations : A pan-Canadian study ( 2001-2011). Managerial Auditing Journal 29(5): 395-426.

Mulgan, R. 2003. Holding Power to Account: Accountability in Modern Democracies. Springer.

Myers, M. D. 1997. Qualitative research in information systems. Management Information Systems Quarterly 21(2): 241-242.

Nalewaik, A. 2013. Factors affecting capital program performance audit findings. International Journal of Managing Projects in Business 6(3): 615-623.

Nath, N. D. 2010. Public Sector Performance Auditing in Fiji: A Hermeneutical Understanding of the Emergence Phase.

Oliver, P. E., \& Myers, D. J. 2003. Networks, Diffusion, and Cycles of. Social Movements and Networks: Relational Approaches to Collective Action 173.

Osborne, S. P., Radnor, Z., Kinder, T., \& Vidal, I. 2015. The Service Framework: A Public service dominant Approach to Sustainable Public Services. British Journal of Management.

Osborne, S. P. 2010. The new public governance. Emerging Perspectives on the Theory and Practice of Public Governance, 1 .

Ostrom, E. 2005. Policies that crowd out reciprocity and collective action. Moral Sentiments and Material Interests: The Foundations of Cooperation in Economic Life: 253275.

Page, S. B., Stone, M. M., Bryson, J. M., \& Crosby, B. C. 2015. Public value creation by cross sector collaborations: A framework and challenges of assessment. Public Administration 93(3): 715-732.

Parker, L. D., Jacobs, K., \& Schmitz, J. 2019. New public management and the rise of public sector performance audit: Evidence from the Australian case. Accounting, Auditing \& Accountability Journal 32(1): 280-306.

Patton, M. Q. 2002. Two decades of developments in qualitative inquiry: A personal, experiential perspective. Qualitative Social Work 1(3): 261-283.

Pearson, D. 2014. Significant reforms in public sector auditstaying relevant in times of change and challenge. Journal of Accounting and Organizational Change 10(1): 150-161.

Performance Measure and Delivery Unit (PEMANDU). 2015. Government Transformation Programme. Prime Minister Department. Putrajaya Malaysia.
Pettas, N., \& Giannikos, I. 2014. Evaluating the delivery performance of public spending programs from an efficiency perspective. Evaluation and Program Planning $45: 140-150$

Pierre, J., Peters, B. G., \& de Fine Licht, J. 2018. Is auditing the new evaluation? Can it be? Should it be? International Journal of Public Sector Management 31(6): 726-739.

Pollitt, C., \& Bouckaert, G. 2011. Continuity and Change in Public Policy and Management. Edward Elgar Publishing.

Provan, K. G., \& Kenis, P. 2008. Modes of network governance: Structure, management, and effectiveness. Journal of Public Administration Research and Theory 18(2): 229252.

Raudla, R., Taro, K., Agu, C., \& Douglas, J. W. 2015. The Impact of Performance Audit on Public Sector Organizations : The Case of Estonia. Public Organization Review.

Reichborn-Kjennerud, K. 2015. Resistance to ControlNorwegian Ministries' and Agencies' Reactions to Performance Audit. Public Organization Review 15(1): 17-32.

Reichborn-kjennerud, K. 2014a. Performance Audit and the Importance of the Public Debate. Evaluation 20(3): 368385.

Reichborn-Kjennerud, K. 2014b. Auditee Strategies: An Investigation of Auditees' Reactions to the Norwegian State Audit Institution's Performance Audits. International Journal of Public Administration 37: 685-694.

Rethemeyer, R. K., \& Hatmaker, D. M. 2008. Network management reconsidered: An inquiry into management of network structures in public sector service provision. Journal of public administration research and theory 18(4): 617-646.

Rhodes, R. A., \& Marsh, D. 1992. New directions in the study of policy networks. European Journal of Political Research 21(1-2), 181-205.

Rhodes, R. A. W. 1996. The new governance: governing without government. Political Studies 44(4): 652-667.

Rhodes, R. A. 1997. Understanding Governance: Policy Networks, Governance, Reflexivity And Accountability. Open university press.

Schillemans, T. 2011. Does horizontal accountability work? Evaluating potential remedies for the accountability deficit of agencies. Administration \& Society, 43(4), 387-416.

Schon, D. A., \& Rein, M. 1995. Frame reflection: Toward the resolution of Intractrable policy controversies. Basic Books.

Scott, C. 2000. Accountability in the regulatory state. Journal of Law and Society 27(1): 38-60.

Siddiquee, N. A. 2010. Managing for results: lessons from public management reform in Malaysia. International Journal of Public Sector Management 23(1): 38-53.

Siddiquee, N. A. 2014. Programme in Malaysia: A Shining Example of Performance Management in the Public Sector? The Government Transformation Programme in Malaysia: A Shining Example of Performance Management in the Public Sector? Asian Journal of Political Science October: 37-41.

Sørensen, E., \& Torfing, J. 2017. Metagoverning collaborative innovation in governance networks. The American Review of Public Administration 47(7): 826-839.

Sørensen, E., \& Torfing, J. 2016. Theories of Democratic Network Governance. Springer.

Sørensen, E., \& Torfing, J. 2007. Introduction governance network research: Towards a second generation. 
In Theories of Democratic Network Governance (pp. 1-21). Palgrave Macmillan, London.

Talbot, C., \& Wiggan, J. 2010. The public value of the National Audit Office. International Journal of Public Sector Management 23(1): 54-70.

Turrini, A., Cristofoli, D., Frosini, F., \& Nasi, G. 2010. Networking literature about determinants of network effectiveness. Public Administration 88(2): 528-550.

Vacca, A. 2014. Court of Auditors' performance auditing as a tool to enhance economy, efficiency, effectiveness and transparency in the public administration, an Italian perspective: strengths and weaknesses. International Journal of Public Law and Policy 4(2): 103-119.

Vangen, S., \& Huxham, C. 2013. Building and using the theory of collaborative advantage. Network theory in the public sector: Building New Theoretical Frameworks: 51-67.

Van Meerkerk, I., Edelenbos, J., \& Klijn, E. H. 2015. Connective management and governance network performance: the mediating role of throughput legitimacy. Findings from survey research on complex water projects in the Netherlands. Environment and Planning C: government and Policy 33(4): 746-764.

Whelan, C. 2011. Network dynamics and network effectiveness: a methodological framework for public sector networks in the field of national security. Australian journal of public administration 70(3): 275-286.
Yang, K. 2012. Further understanding accountability in public organizations actionable knowledge and the structureagency duality. Administration \& Society 44(3): 255-284.

Zarina Zakaria

Faculty of Business and Accountancy

University of Malaya

50603 Kuala Lumpur

MALAYSIA

E-mail: zarinaz@um.edu.my

Sarimah Umor

Faculty of Business and Accountancy

University of Malaya

50603 Kuala Lumpur

MALAYSIA

E-mail: sarimahumor@siswa.um.edu.my

Noor Adwa Sulaiman

Faculty of Business and Accountancy

University of Malaya

50603 Kuala Lumpur

Malaysia

E-mail: adwa@um.edu.my 